\title{
A FELÜLETI ÉRDESSÉG HATÁSA RAGASZTOTT KÖTÉSEK SZILÁRDSÁGÁRA
}

\section{EFFECT OF SURFACE ROUGHNESS ON THE STRENGTH OF ADHESIVE BONDING}

\author{
Palásti-Kovács Béla ${ }^{1}$, Gelencsér Balázs ${ }^{2}$, Czifra Árpád ${ }^{3}$ \\ I'Óbudai Egyetem, Bánki Donát Gépész és Biztonságtechnikai Mérnöki Kar, H-1081 \\ Budapest, Népszínház u.8. Telefon/Fax:+36-1-666-5356, palasti@uni-obuda.hu \\ ${ }^{2}$ Óbudai Egyetem, Bánki Donát Gépész és Biztonságtechnikai Mérnöki Kar, H-1081 \\ Budapest, Népszínház u. 8. Telefon/Fax: +36-1-666-5356, gelencser991@gmail.com \\ ${ }^{3}$ Óbudai Egyetem, Bánki Donát Gépész és Biztonságtechnikai Mérnöki Kar, H-1081 \\ Budapest, Népszínház u. 8. Telefon/Fax: +36-1-666-5391, czifra.arpad@bgk.uni- \\ obuda.hu
}

\begin{abstract}
Nowadays adhesive bounding becomes more and more popular in jointing of machine elements. It is important to know, how surface finishing and microgeometric preparation influence the jointing strength. In present study, shearing strength was examined using different type of adhesives of Loctite and Teroson (epoxy, acril, cianacrilat, MS polymer) and different surface roughness, but same layer thickness. After defining the optimal surface roughness the connection between layer thickness and jointing strength was investigated. Based on more than hundred tests, conclusions about the importance of surface roughness were drawn. It was proved that, surface roughness highly influence the adhesive bounding and the optimal layer thickness - connected to the bonding material - also has great influence to joint strength.
\end{abstract}

Keywords: surface roughness, adhesive bonding, joint strength.

\section{Összefoglalás}

Napjainkban a gépelemek szilárd összekapcsolásában, rögzítésében egyre nagyobb szerepet kap a ragasztás. Kérdés, hogy a ragasztott felületek mikrogeometriai elökészítése, felületi érdessége mennyire és milyen módon befolyásolja a ragasztás erősségét. Dolgozatunk keretében vizsgáltuk a nyírószilárdság függését különböző típusú Loctite, illetve Teroson márkájú ragasztónál (epoxi, akril, ciánakrilát, MS polimer), eltérő felületi érdességeknél, azonos rétegvastagságnál. Vizsgáltuk továbbá az előzőekben már meghatározott optimális érdességek mellett a nyírószilárdság és ragasztási rétegvastagság kapcsolatát is. Az elvégzett több mint száz kísérleti kiértékelésből következtetéseket vontunk le az érdesítés szerepéről a ragasztott felületek előkészítésénél. Rámutatunk arra a tényre, hogy megfelelő érdesítés mellett sokkal jobb eredményt várhatunk el az adott ragasztástól. Kiemeljük azt is, hogy a megfelelő ragasztóhoz és ragasztandó anyaghoz a megfelelő (optimális) ragasztási rétegvastagság kiválasztásának nagy jelentősége van.

Kulcsszavak: felületi érdesség, ragasztott kötés, kötési szilárdság. 


\section{Bevezetés}

A világon ma az ipari termékek kb. 1520\%-át ragasztóanyagok felhasználásával állítják elö, és ez az arány várhatóan növekedni fog. A ma készült ragasztók megbízhatósága és teherbírása vetekszik más kötési módok terhelhetöségével. A ragasztóanyagok jelentősége abban rejlik, hogy különböző alapanyagú elemeket is képesek szilárdan összekötni.

A fémragasztás technikája az 1940-es években forrott ki a repülőgép- és hadiipar számára. A ragasztástechnika fejlődéséhez a piaci igények és olyan tapasztalatokkal rendelkező nagyvállalatok kutatómunkája járult hozzá, mint a ragasztástechnikában élen járó Loctite cég.

A ragasztások készítésekor az összekötendő darabok felületkezelése is szükségessé válik. Itt jelenik meg a felület mikrogeometriája (érdessége) és annak szerepe a ragasztott kötés szilárdságára [1].

\section{A felületi érdesség és a szakító- szilárdság}

A ragasztott kötések nyírószilárdsága és a felületi érdesség nagysága között különböző javaslatokat találunk. Szemcseszórt fémfelületek vizsgálatánál Rmax $=7 \mu \mathrm{m}$-nél a legkisebb a nyírószilárdság, s ha ezt különböző beesési szögekkel durvítják, akkor ezzel a szilárdság is nő [1].

Már az 1950-60-as években megállapították, hogy a felületi érdességi értékeknek nincs nagy jelentősége: „Lényegesen finomabb és durvább felületek esetén sem mutatkoztak jelentős szilársági eltérések" [2]. Napjaink vizsgálatai [3] pontosítják ezeket az eredményeket. Megállapítják, hogy a felület amplitúdó paramétereivel csak gyenge korrelációt mutat a kötés erőssége, ugyanakkor a felület hibrid paraméterei erősen befolyásolják a kötési szilárdságot.
Ennek ellenére az ipari gyakorlat továbbra is elsősorban az érdesség magassággal jellemzi a ragasztott felületeket.

Az 1980-as évek Loctite ajánlásaiban ragasztott kötésekhez az 1. ábra szerint $\mathrm{Rz}=25 \ldots 40 \mu \mathrm{m}$ egyenetlenség-magasság adja a legkedvezőbb nyírószilárdságot $\left(\mathrm{f}_{3}\right.$ faktor). Ez azt jelentette akkor, hogy a szilárd illesztések finomságához $(\mathrm{Rz}=2,5 \ldots 6,5 \mu \mathrm{m})$ képest jelentős költségmegtakarítást eredményezhetett a ragasztás [4], s így a mechanikus finommegmunkálás elhagyása.

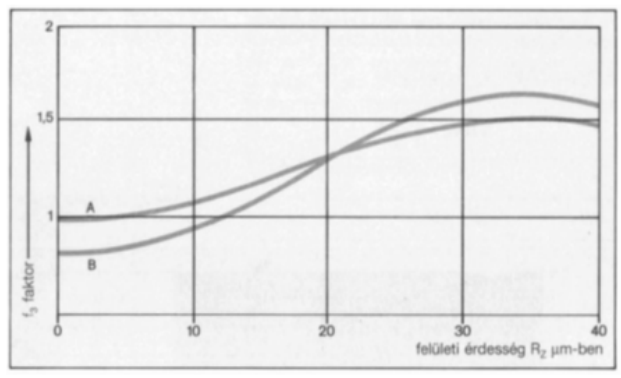

1. ábra. $A z f_{3}$, faktor a szilárság az érdesség függvényében különbözố LOCTITE típusokhoz. [4]

Az újabb Loctite vizsgálatokban azt tapasztalták, hogy forgácsoló megmunkálással előkészített ragasztandó felületeknél általában az $R \max =8-12 \mu \mathrm{m}$ maximális felületi érdesség (2. ábra) adta a legkedvezőbb kötésszilárdságot [5].

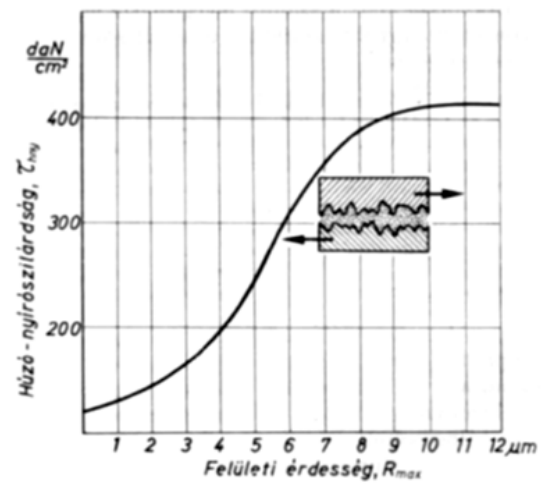

2. ábra. A ragasztás nyírószilárdsága és az érdesség kapcsolata [5] 


\section{Kísérleti vizsgálatok leírása}

A felületi korrózió elkerülése miatt X8CrNi1810 korrózióálló acél próbatesteket készítettünk elő szemcseszórással, különbözö felületi finomságúra. Öt érdességi csoportot (25 - $25 \mathrm{db}$ ) különítettünk el, s az előkészítés után mértük és átlagoltuk a felületi érdesség Ra, Rz, Pa, Pz paramétereit. A csoportok átlagértékeit az 1. táblázat foglalja össze.

1. táblázat. Az érdességi csoportok paraméterértékei

\begin{tabular}{|c|c|c|c|c|}
\hline Cs. & $\begin{array}{c}\mathrm{Ra} \\
{[\mu \mathrm{m}]}\end{array}$ & $\begin{array}{c}\mathrm{Rz} \\
{[\mu \mathrm{m}]}\end{array}$ & $\begin{array}{c}\mathrm{Pa} \\
{[\mu \mathrm{m}]}\end{array}$ & $\begin{array}{c}\mathrm{Pz} \\
{[\mu \mathrm{m}]}\end{array}$ \\
\hline 1. & 1,45 & 9,74 & 1,55 & 11,56 \\
\hline 2. & 2,16 & 18,27 & 5,83 & 36,98 \\
\hline 3. & 3,15 & 25,00 & 11,46 & 57,18 \\
\hline 4. & 5,40 & 37,56 & 11,00 & 68,06 \\
\hline 5. & 6,67 & 46,09 & 12,45 & 77,38 \\
\hline
\end{tabular}

A mérési eredményekből látható, hogy a csoportok jól elkölöníthető érdességgel rendelkeznek, de azt is ki kell emelni, hogy a szürt $\mathrm{Rz}$ értékek és a szüretlen (valóságban működő P-profil) Pz értékek jelentősen eltérnek egymástól [6].

A Loctite 401 és 326-os ragasztók esetében null-hézaggal, míg a Loctite 3430 és a Toroson MS 9399 esetében 0.5 mm-es hézaggal végeztük el a ragasztást (Loctite ajánlás). A megfelelő kötési idő eltelte után került sor a szakításokra TTM 100-as univerzális szakítógéppel. A szakítódiagramokat és a nyírószilárdság értékeit rögzítettük.

\section{Kísérleti eredmények kiértéke- lése: érdesség - nyírószilárdság kapcsolata}

A mérések eredményeit oszlopdiagramokban vethetjük össze. Ezekből egyértelmüen meghatározható az adott körülményekhez viszonyított optimális felületi érdesség. Három ragasztónál a ragasztási szilárdság $\quad \mathrm{Rz}=18,27 \mu \mathrm{m}$ egyenetlenség magasságig nőtt, itt adta a maximális szilárdságot, majd csökkent. A csökkenés után némi növekedés is megfigyelhetö volt a 3430 és az MS 9399 ragasztónál (3. ábra).
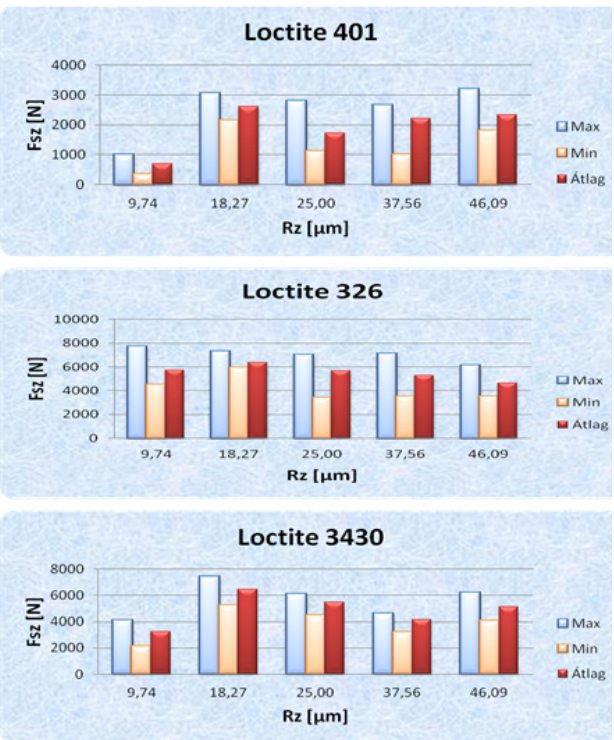

3. ábra. A ragasztás nyirószilárdsága és az érdesség kapcsolata kisérleteinkben

Az MS 9399 ragasztónál az Rz érték növekedésével növekedett a ragasztási szilárdság is (4. ábra). A méréseknél megfigyelhető viszonylag nagy szórás annak tudható be, hogy szemcseszórással nem lehet teljesen homogén felületet előállítani, mivel kicsit változik a pisztoly és a munkadarab távolsága, egymáshoz viszonyított helyzete.

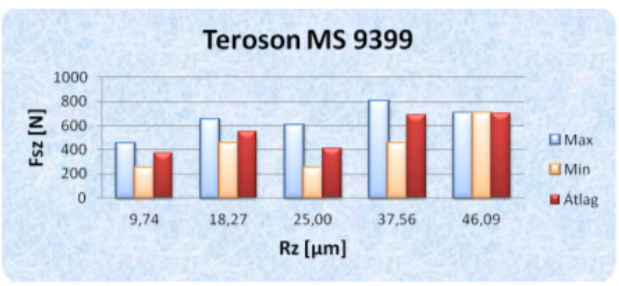

4. ábra. A ragasztás nyirószilárdsága és az érdesség MS 9399 ragasztónál 
Vizsgáltuk a ragasztási szilárdságot különböző ragasztási hézagoknál is, az előzőekben megismert optimális $\mathrm{Rz}=18,27 \mu \mathrm{m}$ átlag-érdesség mellett a Loctite 401, Loctite 326, és Loctite 3430 ragasztónál. A választott ragasztási hézagok: 0,01 mm; 0,04 mm; $0,1 \mathrm{~mm}$ voltak, melyeket megfelelő hézagoló lemezzel biztosítottunk. Az eredményeket az 5. ábra mutatja be.
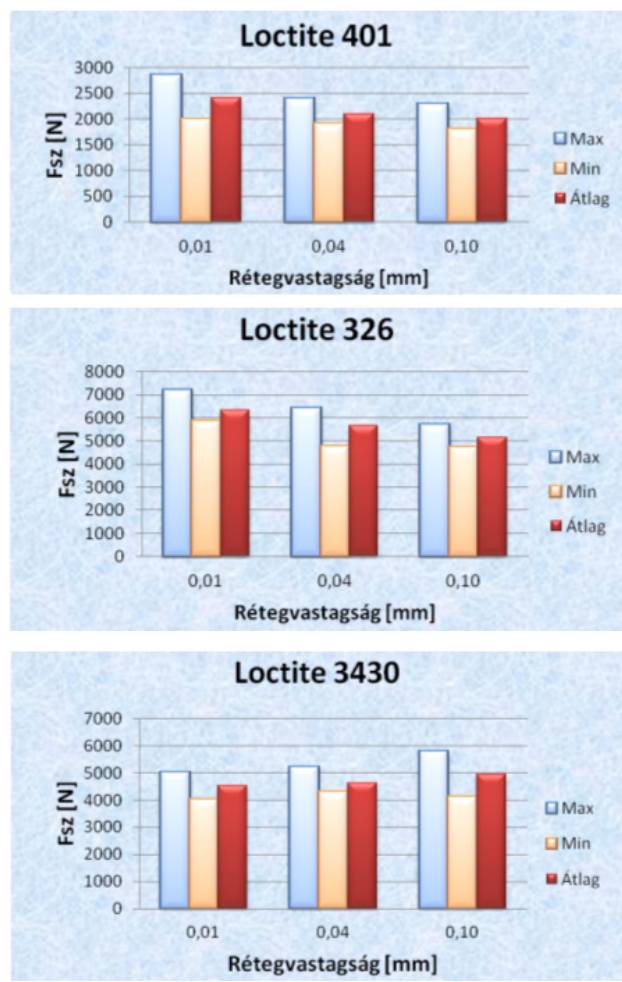

5. ábra. A ragasztás nyírószilárdsága és a ragasztási hézag kapcsolata

Kiértékelve az eredményeket egyértelmüen látszik, hogy a Loctite 401 és a Loctite 326 esetében a kisebb, míg a Loctite 3430 esetében a nagyobb ragasztási hézag a kedvezőbb.

\section{4. Összegzés, következtetések}

A ragasztásnál a helyes felületi érdesség megválasztásával a gyártási költségek és a selejtek száma nagyban csökkenthető, illetve jelentős szilárdsági, s így tartóssági növekedést érhetünk el.

A mérések alapján kiderült, hogy felületi érdességnek jelentős befolyásoló szerepe van a ragasztás kötési szilárdságára.

A kísérletek alapján kijelenthető, hogy az X8CrNi1810 korrózióálló acélból készült próbatesteknél, a vizsgált ragasztóknál, egy kivétellel az $R z=15-20 \mu$ m-es érdességi tartományban legjobb a ragasztás szilárdsága. Kivétel az MS 9399 volt, itt az érdesség növekedésével nőtt a kötési szilárdság is.

A rétegvastagság kötési szilárdságra gyakorlot hatása a ragasztóanyagtól függ. Egyes esetekben a kisebb, míg más esetekben a nyagobb rétegvastagság kedvező.

A Henkel JointCalc2.0 programmal szimulálja a ragasztott kötéseket. A fentiek alapján javasoljuk, hogy a ragasztandó felületek érdessége is változóként szerepeljen a szimulációs programban.

$\mathrm{Az} R$ érdességi paraméterek és a $\mathrm{P}$ szüretlen profil paraméterei között jelentős különbség van, ami felveti azt a kérdést is, hogy melyik típusú paramétert célszerü alkalmazni az elöírások során.

\section{Szakirodalmi hivatkozások}

[1] Gelencsér Balázs: ÓE-BGK Szakdolgozat:

"A felületi érdesség és a ragasztás kapcsolata Ko33 lemez próbatesteknél” 2014. 06.

[2] Ragasztástechnikai Zsebkönyv, Balázs Gyula, Müszaki Könyvkiadó Budapest 1976

[3] W. Zielecki, P. Pawlus, R. Perlowski, A. Dzierwa: Surface topography effect on strength of lap adhesive joints after mechanical pre-treatment, Archives of Civil and Mechanical Engineering 13 (2013) 175-185

[4] Der LOCTITE (C1988, LOCTIE Deutschland $\mathrm{GmbH}$. 2. átdolgozott kiadás

[5] Loctite: Worldvide design handbook, 2. javított kiadás (C1998 Loctite European Group Munich, Germany (ISBN 0-96 5590-0-5)

[6] Dr. Palásti-Kovács, - B. Pintér, L. - Dr. Czifra, Á.: Relationship between tolerance and surface roughness II. XIX. FMTÜ2014.03.19-20. 321-324. 